

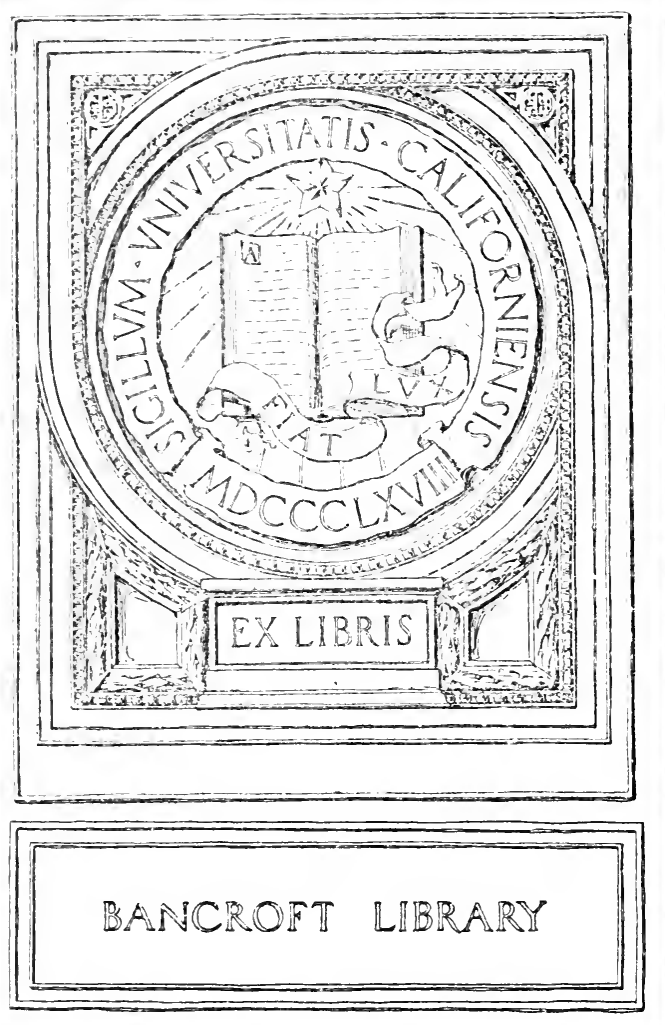



Digitized by the Internet Archive in 2007 with funding from Microsoft Corporation 

Spanish Seamen in the New World During the Colonial Period

PAUL s. SAY $_{\text {TAYOR }} 1895^{\circ}$

Reprinted from The Hispanic American Historical Review, Vol. V, No. 4, November, 1922

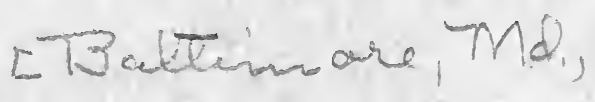




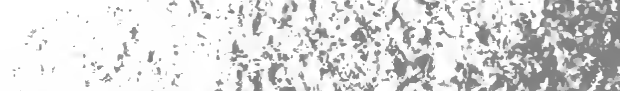

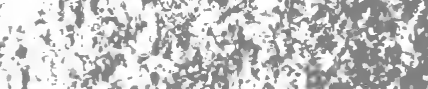

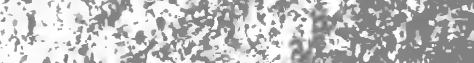

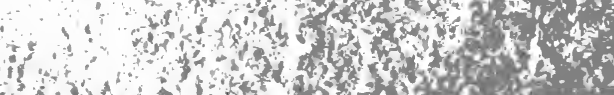

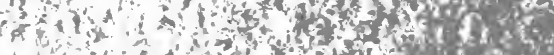

and

1

- 1 en

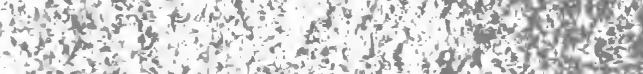

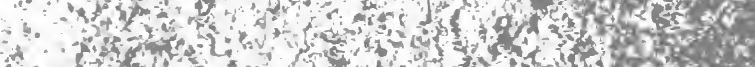

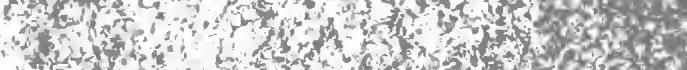

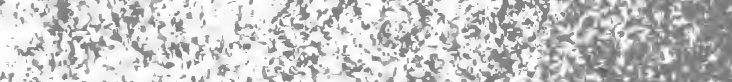

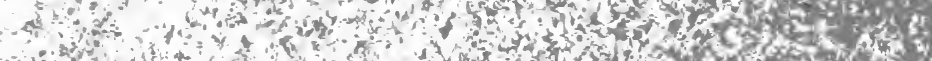

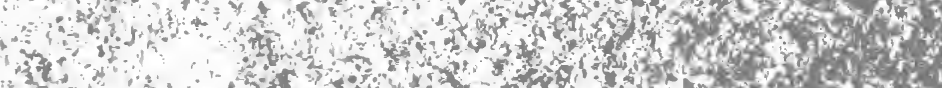

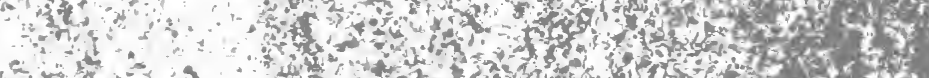

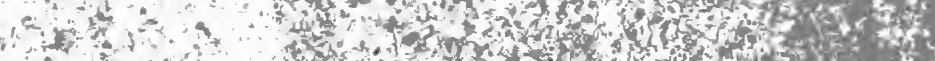

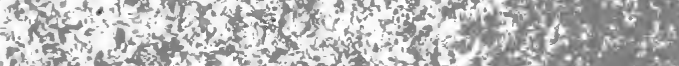

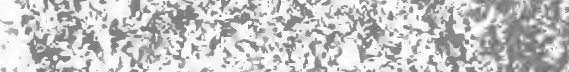

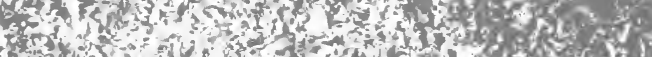

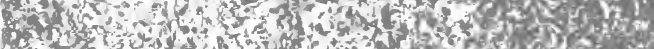

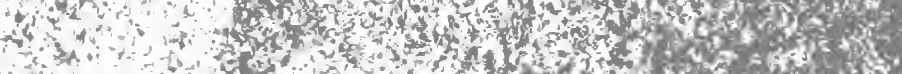

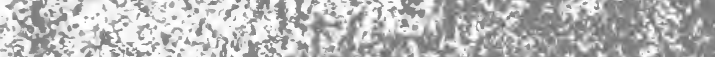

1.

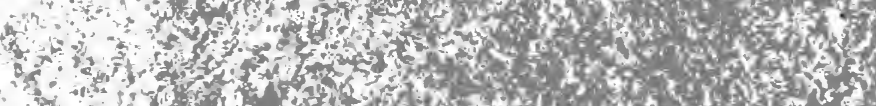

H.

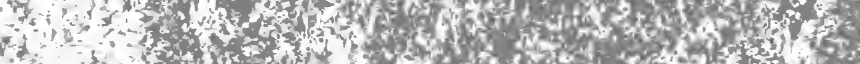

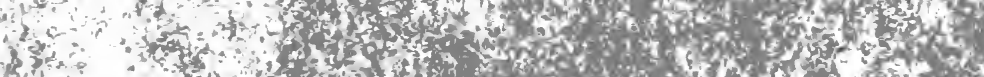

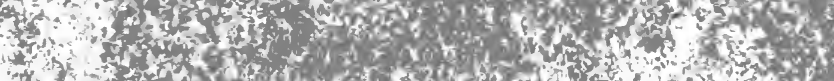

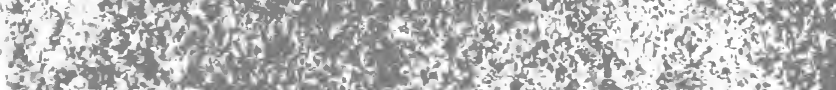
3013 a

u (4)

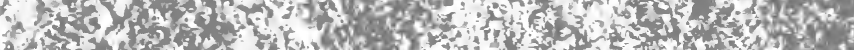

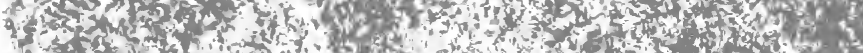

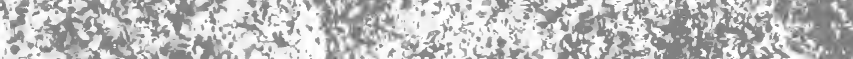

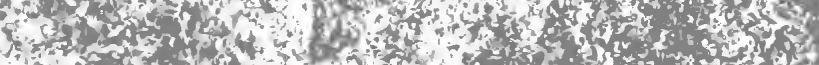

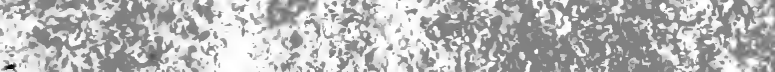

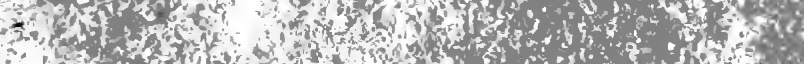

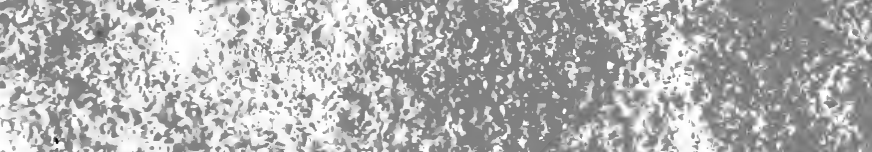

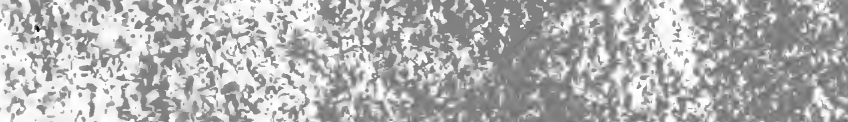
its

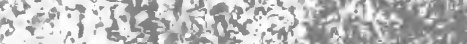

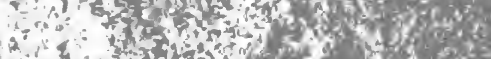

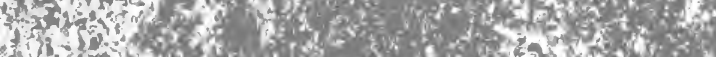

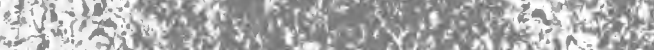

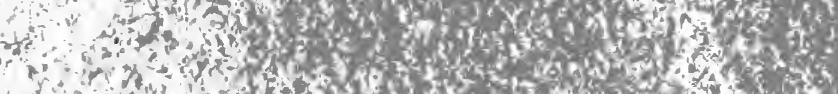

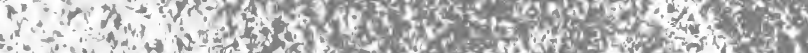

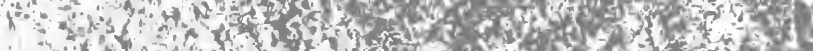

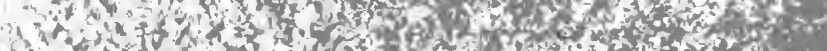

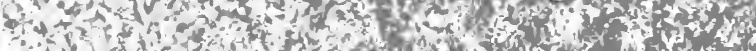
a.c.

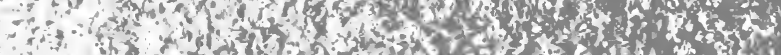

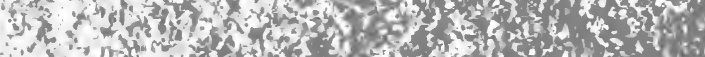




\section{SPANISH SEAMEN IN THE NEW WORLD DURING THE COLONIAL PERIOD}

\section{THE LEGAL STATUS OF SPANISH SEAMEN}

The Spanish mariners of the New World were governed by the laws of the Indies. Their conditions of service were perhaps more vitally affected by the manner in which masters of ships saw fit to exercise (or exceed) their authority. But beneath both enactments and arbitrary authority lay the Consulado del Mare, the maritime law at the basis of all legal relationships of the sea, just as the Common Law is at the basis of all our legal relationships on land. For this reason, an analysis of the customs of the sea, as contained in the Consulado del Mare, is especially valuable as furnishing a background for a sketch of the conditions of life among seamen of the colonial period.

The Consulado del Mare furnished the laws used by practically all the Consulados of Spain, which for three or four centuries were accepted as authority throughout the Mediterranean area. It also furnished the basis of the laws of Oleron of about the same period. The Consulado del Mare was compiled at Barcelona, in all probability, according to an eminent authority, "by the scribe of the Consular Court for the use of the Consuls of the Sea."' The exact date of its origin is a subject of some disagreement. Perhaps the more general opinion is that the laws were compiled during the thirteenth century. This is the view of such men as Capmany, Vinino, and Meyer. ${ }^{2}$ Twiss, writing at a later date

${ }^{1}$ Sir Travers Twiss, ed., Monumenta juridica ... . . The Black Book of the Admiralty, 4 vols. (London, 1871-1876. III. lxxxix. Hereafter cited as, Black book.

${ }^{2}$ Antonio de Capmany y de Montpalou, Memorias historicas sobre la marina, comercio y artes de la antigua cuidad de Barcelona, 4 vols. (Madrid, 1779-1792.) I. part II. 175. Also see Charles Solomon Mitrani, "The Rise of the Spanish Consulados . . . Berkeley, 1917" (unpublished manuscript in the University of California Library). 
(1874), states that he "considers the assumption to be well founded that the Customs of the Sea in the form in which they have come down to us in the Book of the Consulate of 1494 were not compiled until some time after 1340 A.D."'3 But regardless of the exact date of origin, it is known that the Consulado del Mare was the recognized maritime law of the South European countries for several centuries.

The Consulado mentions six modes of hiring mariners: (1) for the agreed voyage at a lump sum; (2) by the month; (3) by the mile; (4) at the discretion of the managing owner; (5) for a share in the freight; (6) for the right to load goods on their own account. ${ }^{4}$ The contract of hiring was entered into when the mariner's name was entered on the ship's register, or he had shaken hands with the managing owner, a ceremony as binding as if they had gone before a notary..$^{5}$ In addition, an oath of loyalty was required from mariners and all who received wages aboard ship. ${ }^{6}$ Once the contract was made, the mariner could go nowhere except with the consent of the managing owner. ${ }^{7}$ And the managing owner, on his part, could not dismiss the mariner unless it was upon one of four conditions: (1) robbery; (2) quarreling; (3) disobedience, and then only upon the fifth occasion; or (4) breach of oath. ${ }^{8}$

The mariner's duties comprised anything he might be ordered to do about the ship and its navigation. In the words of the Consulado,

- . the mariner is bound in all things which pertain to the ship, to go to the forest and fetch wood, to saw and to make planks, to make spars and ropes, to bake, to man the boat with the boatswain, to stow

${ }^{3}$ Black book, II. lxv.

4 Ibid., III. 191, note 1.

5 "Coustumes de la Ville de Barcelone concernant la Marine et diverses Ordonnances des Rois d'Aragon en langue Catalane [Consulado del Mare]." Original text and translation in Black book, III. 50-657. Ch. cix. in, Black book III. 217. (Chapter citations refer to both texts; page citations in the Black book are given only for the English translation. The original text may be found on the opposite page.)

'Ibid., Ch. xvi. in Black book, III. 89.

${ }^{7}$ Ibid., Ch. cix. in Black book, III. 217.

8 Ibid., Ch. lxxx. in Black book, III. 187. 
goods and to unstow them; and at every hour when the mate shall order him to go and fetch spars and ropes, to carry planks, and to put on board all the victuals of the merchants, to heave the vessel over, to go and fetch spars and ropes, to carry planks, and to aid to repair the vessel, and he is bound to do everything to improve the condition of the ship and of all which belongs to the ship whilst he shall be engaged to the ship. ${ }^{9}$

A passage rather curious from our viewpoint, but not from the mariner's, attests the fact that he was never free from duty for very long intervals:

A mariner ought not to undress himself if he is not in a port for wintering. And if he does so, for each time he ought to be plunged into the sea with a rope from the yard arm three times; and after three times offending, he ought to lose his salary and the goods which he has in the ship. ${ }^{10}$

In those days, vessels were not always accustomed to draw up alongside of wharves, so the mariner must be willing to step into the water himself and carry the passengers ashore upon his back; and if he was not willing, he was bound to reimburse the passenger any loss he might incur. ${ }^{11}$

In general, freight was the mother of wages. But the mariner was safeguarded against loss through unprofitable voyages, for the Consulado held that in the last resort, the ship was liable for wages, even to the extent of selling the vessel.12 One source of mariners is indicated by the following passage concerning wages:

- . the managing owner may not diminish the wages of any one. And if a man is worth more than the managing owner believed at the commencement, he ought to increase his wages; for many men desire to leave a country, because they are not sufficiently appreciated, and in order to get away from it, sell their personal services at a cheap price. ${ }^{13}$

- Ibid., Ch. cx. in Black book, III. 219.

10 Ibid., Ch. cxxv. in Black book, III. 233. "Ought" should generally have been translated as "must."

${ }^{11}$ Ibid., Ch. cxxxi. in Black book, III. 235.

12 Ibid., Ch. xciii. in Black book; III. 199.

13 Ibid., Ch. cv. in Black book, III. 215. 
But evidently all mariners were not so eager to escape from the country that they were willing to take low wages. For it is also provided as follows:

Here let us suppose that the managing owner of a ship agrees with a mariner, be he bad or good, skilful or unskilful, he has to pay him his wages, nevertheless under this condition, that if the mariner has represented himself to be a caulker or a carpenter or a mate, and the managing owner has hired him upon that reliance, if the mariner knows nothing, the managing owner of the ship or vessel is not bound to give him anything beyond what the mate and the ship's clerk adjudge upon their oath that he ought to have. ${ }^{14}$

A mariner who shipped for wages by the mile was bound to go wherever the ship went, even "to the end of the world". But if he signed for a voyage, then he was bound only for the particular voyage agreed upon. And if the vessel should be sold before returning, it was the duty of the owner to provide him with a ship to return to his home port. ${ }^{15}$

A customary scale of rations, enumerated in considerable detail, is called for by the Consulado:

- . the managing owner of a ship or vessel, which is decked, ought to give to eat to the mariners on three days a week flesh-meat, that is to say on Sundays, Tuesdays, and Thursdays, and on the other days of the week porridge, and every evening of every day accompaniment with bread, and also on the same three days in the morning he ought to give them wine, and also he ought to give them the same quantity of wine every evening. And the accompaniment of the bread ought to be such as follows, that is, cheese or onions or sardines or some other fish. . . . Further the managing owner of the ship or vessel is bound to double the ration of the mariners upon the solemn feast days. Further, he ought to have servants to prepare the food for the mariners. ${ }^{16}$

Compared to the sea code of the Hanse Towns (which authorized branding on the forehead), the penalty for desertion stipu-

14 Ibid., Ch. lxxix. in Black book, III. 187.

${ }^{15}$ Ibid., Ch. cxvi. in Black book, III. 225.

16 Ibid., Ch. c. in Black book, III. 211, 213. 
lated in the Consulado was mild. The mariner was bound to make compensation to the owner for all losses incurred as a result of the desertion, and in case he was unable to do so, he could be imprisoned until such time as he was able to pay.17 And mariners who took away a ship without the consent of the owner were similarly bound to make losses good, and could be imprisoned, and a demand made against them, "just as against persons who renounce their lord and dispossess him of his authority."

Discipline aboard ship was of course to be very strictly enforced. Necessarily much authority was left to the master, and the mariner must be extremely careful in his conduct towards him. A mariner who quarreled with the managing owner lost half his wages and the goods he had in the ship. ${ }^{18}$ And heavier penalities were exacted in proportion to the gravity of the offense.

. . . And if he raises a weapon against the managing owner, all the mariners ought to seize him and bind him and put him into prison, and take him before the local authorities, and those who will not seize him ought to lose their goods and the wages which they will receive or ought to receive for the voyage..$^{19}$

Thus it was made the duty of the crew to assist actively in disciplining itself. But the paragraph of the Consulado which deals with the limits of the mariners' right of self defense, shows most clearly his real status aboard ship.

Further, a mariner is bound to bear with the managing owner of a ship, if he reproaches him, and if he runs to attack him themariner ought to run away to the bow of the ship and place himself by the side of the chain. And if the managing owner passes the chain, he ought to run away to the other side, and if the managing owner passes to the other side, he may defend himself, calling persons to witness how the managing owner ought not to pass the chain. ${ }^{20}$

${ }^{17}$ Ibid., Ch. cxiii. in Black book, III. 221.

${ }^{18} \mathrm{Ibid}$., Ch. cxviii. in Black book, III. 227, 229.

19 Ibid.

20 Ibid., Ch. cxx. in Black book, III. 229. 


\section{THE SEAMEN OF THE EXPLORERS}

Spanish navigators explored the west coast of America from the Horn to Alaska, and across the Pacific to the Orient. Their ships were manned by rough, hardy seamen who underwent untold hardship and suffering from unremitting battle with wind. and wave, cold, exposure, starvation, disease, and death.

It was the policy of the king to allow none but Spanish mariners in the New World, for reasons of greater secrecy surrounding the wealth of his possessions. Nevertheless, it was found necessary to enlist foreign sailors, especially in the earlier expeditions, because native Spanish seamen were lacking. Thus Magellan carried besides the Spanish among his crew of 265 men, some 37 Portuguese, 30 or more Genoese and Italians, 19 French, and others were Flemings, Germans, Sicilians, English, Corfiotes, Malays, Negroes, Moors, Madierans, Biscainers, and natives of the Azores and Canary Islands. ${ }^{21}$ In 1565 many Portuguese sailed to the Philippines with Legazpi and caused him considerable anxiety, because in view of the relations between the two nations, he found them not to be trusted.22 The sailors for the later expeditions up the California coast were most probably all Spaniards, or natives of the vicinity of San Blas, as in the expedition of Martinez. ${ }^{23}$

In the main, the men seem to have served and sacrificed with great fortitude, if not always with obedience, thoughts of glory or love of adventure proving sufficient stimulus. Probably on such expeditions a sufficient number of volunteers could be found, if not all Spanish, then of other nationalities. At least

${ }^{21}$ Andrea Ca da Mosto, Il primo viaggio intorno al globo di Antonio Pigafetta (Roma, 1894), p. 53, note 2. Quoted in translation in Emma Helen Blair, and James Alexander Robertson, ed. and transl. The Philippine Islands, 1493-1898, 55 vols. (Cleveland, 1903-1908). XXXIII. 279. The latter work is cited hereafter as Blair and Robertson.

22 Miguel López de Legazpi, Copia de una Carta que escribio. . . al Marques de Falces, Cebu, July 7, 1569. Translation in Blair and Robertson, III. 44-53. See p. 53.

${ }^{23}$ Estevan Josef Martinez, Diary of the Voyage . . in . . the frigate Princesa and the packet San Carlos . . . in the present year of 1789. Translation by W. L. Schurz, p. 62 (unpublished manuscript in the Bancroft Library). 
the writer has found but one case of shanghaiing recorded-that of a man from the island of Teneriffe who was forcibly added to the crew by the order of Magellan. ${ }^{24}$

The sailors were a rough class of men, intemperate (if the example of the seaman on Bodega's schooner who drank himself to death is at all typical of their love of strong drink), ${ }^{25}$ given to excesses when they went ashore, ${ }^{26}$ commonly afflicted with venereal diseases, ${ }^{27}$ irresponsible, and turbulent. They loved to gamble and to barter, even with the very clothes they wore. When Vizcaino issued out the extra supply of clothing at the request of his men, to protect them from the cold, he thought it necessary to issue at the same time an edict "to the effect that no one should gamble or sell them, under pain of death."'28 Maurelle records that his men cut their shirts, trousers, and jackets into strips, and bartered these little rolls or bandages with the Indians. ${ }^{29}$ And Governor Fages of California ordered that no bales of goods should be opened until the San Blas vessels left port, to avoid the waste of clothing in barter with the sailors. ${ }^{30}$

Mutinies were of frequent occurrence, especially in the expeditions which crossed the Pacific. Although seamen took part in these uprisings against authority, they were often led by men of higher rank, actuated by motives of jealous ambition, who found discontented elements in the crew ready to aid them. Thus, royal officials led a mutiny against Magellan, which he suppressed

24 Blair and Robertson, XXXIII. 289, note 1.

${ }^{25}$ Francisco Antonio Maurelle, Journal of a voyage in 1775 . . in the King's schooner, called the Sonora, and commanded by Don Juan Francisco de la Bodega. Translation in Barrington, Miscellanies . . . (London, 1781), pp. 471-534. See p. 480.

${ }^{26}$ Francisco Antonio Maurelle, Narrative of an interesting voyage in the frigate La Princesa, from Manila to San Blas in 1780, and 1781. Translation in La Perouse, $A$ voyage round the world, in the years $1785,1786,1787$, and 1788. 3 vols. (Translated from the French, 1791), I. 340-418. See p. 375.

${ }^{27}$ Martinez, supra, p. 58.

${ }^{28}$ Sebastian Vizcaino, Diary, 1602-1603. Translation in Herbert Eugene Bolton, ed., Spanish Exploration in the Southwest, 1542-1706 (New York, 1916), pp. 52-103. See p. 57.

29 Narrative of an interesting voyage in the frigate La Princesa, from Manila to San Blas in 1780, and 1781. Translation in La Perouse, op. cit., I. 372.

30 Hubert Howe Bancroft, Works, 39 vols. (San Francisco, 1882-1890), XVIII. 484. 
by executing the ringleaders. ${ }^{31}$ But a short time thereafter a second mutiny broke out. The crew of the San Antonio put their captain, Alvaro, in irons, and after many difficulties returned to Spain. ${ }^{32}$ Mutinies broke out in the expeditions on the Pacific sent out by Cortes. One of the ship's companies mutinied against their commander Hurtado de Mendoza, and returned to port. ${ }^{33}$ Another expedition came to an unfortunate end when Ximines, in 1534, killed his superior, Bercerra, and took command, only to be himself killed soon afterwards by Indians. ${ }^{34}$ In 1537 the explorer Grijalva was killed by mutineers. ${ }^{35}$ The crew of one of the ships of Loaysa, in the South Pacific, mutinied, throwing the captain and his brother overboard. Like most of the mutinous crews, they ran into difficulties. The ship went aground on an island and the crew were overpowered by Indians. Saavedra, crossing the Pacific from New Spain, found them, and brought the mutineers to justice. ${ }^{36}$ The Legazpi expedition to the Philippines in 1565 also has its record of mutinies. On the first occasion Legazpi hanged four leaders, severely reprimanded others, and as for the rest, merely imposed the order that no language but Spanish be spoken. When a second mutiny occurred, two more were hanged. The San Geronimo, sent to aid Legazpi, had similar experiences. The captain and his son were murdered by mutineers; and two of the latter were hanged following a second, and successful counter mutiny. ${ }^{37}$

This frequency of mutiny no doubt reflected somewhat on the severity of discipline aboard ship. The death penalty was inflicted for mutiny and other crimes, and at least threatened for lesser offenses. Bodega seems to have been a commander who treated his men with great consideration. When they became

${ }^{31}$ Maximilianus Transylvanus, De Molvccis Insulis. [Coloniae, 1523] Translation in Blair and Robertson, I. 305-337. See p. 318.

32 Ibid., p. 219.

${ }^{33}$ Miguel Venegas, A natural and civil history of California . . . Translated from the original Spanish . . 2 vols. (Madrid, 1758). I. 133.

${ }^{34}$ Ibid., I. 135.

25 James Burney, A chronological history of the discoveries in the South Sea. . . 4 vols. (London, 1803), I. 181.

ab Ibid., I. 149.

${ }^{37}$ Blair and Robertson, II. 143, 144, 148, 149. 
discouraged he gave them small presents, and in other ways stimulated their enthusiasm. ${ }^{38} \mathrm{He}$ took all precautions he was able to against sickness and scurvy. Yet when two of his men voluntarily went among the Indians, intending to remain, but were made captives, causing Bodega much trouble in securing their release, the commander had them laid across cannon and each given a hundred lashes, after which he put them in irons. ${ }^{39}$ It was considered to be, and was made the duty of commanders to punish severely blasphemy, gambling, immorality, and other sins. Before departing on the expeditions, sailors were required to take an oath of loyalty to the commander that they would obey him and not mutiny, and they had to present a certificate that they had confessed and received communion. ${ }^{40}$ Of those who were enlisted for the voyages, not only their name, but their father's name and his place of birth were entered on the register, that their nationality might be known. ${ }^{41}$

The explorations were hazardous undertakings. Nearly every expedition suffered losses from attacks by Indians when the crew went ashore for food, wood, and water. The navigation of the small craft required much labor and exertion of the sailors, especially when storms were encountered, which was often. The schooner Sonora in which Bodega conducted his exploration up the coast in 1775 was but 36 feet long, 12 feet wide, and 8 feet deep, and carried a crew of a pilot, boatswain, boatswain's mate, ten sailors, a cabin boy, and a servant.42 Not all the vessels

${ }^{38}$ Maurelle, Journal of voyage in 1775 , supra. Translation in Barrington, op. cit., pp. 478,479 .

${ }^{39}$ Juan Francisco de la Bodega y Quadra, Second voyage to the latitude of sixty-one degrees in the frigate Nuestra Señora de los Remedios, alias La Favorita, having a keel of thirty-nine cubits and a breadth of beam of thirteen, with a draught aft of fourteen feet, and a draught forward of thirteen feet. In the year 1779. Translation by Herbert I. Priestley, p. 28. (Unpublished manuscript in the possession of Herbert I. Priestley, Berkeley, California.)

40 Blair and Robertson, II. 61, 62, 91.

${ }^{41}$ Ibid., II. 57.

42 Bodega y Quadra, First voyage to the latitude 58 degrees, in a schooner having a keel of eighteen cubits and breadth of beam of six, manned by a pilot, a boatswain, a boatswain's mate, ten sailors, a cabin-boy, and a servant. In the year 1775. Translation by Mrs. Gertrude Mason, p. 1. (Unpublished manuscript in the possession of Herbert I. Priestley, Berkeley, California.) 
used were so small, yet the best of them were not large, and afforded but poor protection to the mariners. Huge waves would come sweeping over the gunwales, carrying away everything above deck. On such a schooner as the Sonora, except in a calm, the sailors could not perform their duties on the ship without becoming thoroughly wet. ${ }^{43}$ Since they were used to a warmer climate, they suffered greatly from the cold of the northern latitudes. Their clothes became soaked by the rain and spray, so that in spite of the extra issue of clothing provided by the king, large numbers fell sick with severe colds contracted from fatigue and exposure. There were no conveniences for their care and protection, and few medicines. Consequently many seamen died, and the work of exploration was hampered accordingly.

The seamen's rations which Magellan supplied for his voyage included wine, olive oil, vinegar, fish, pork, peas and beans, flour, garlic, cheese, honey, almonds, anchovies, raisins, prunes, figs, sugar, quince preserves, capers, mustard, beef, and rice. ${ }^{44}$ Other Spanish explorers carried similar provisions, though probably none so complete a list. Martinez carried aboard his frigate to Nootka Sound some goats, hogs, cows and calves. ${ }^{45}$ But not all ships were so well supplied. Often the men were forced to go on short rations. For instance, Maurelle tells how he was obliged to reduce the allowance to five ounces of bread, three of pork, and two of beans, per day; and many cases were far worse than his. ${ }^{46}$ Even so, the sailors would generally have been adequately provided for, but for the spoiling of the rations aboard ship. Fresh food would not remain fresh long, but soon all became corrupted. The ships were dirty and swarming with vermin and rats which attacked the rations. On board Maurelle's ship the cockroaches reduced the biscuit to a powder, and

${ }^{48}$ Maurelle, Journal of a voyage in 1775, supra. Translation in Barrington, op. cit., p. 478.

44 Blair and Robertson, XXXIII. 278, note 25.

${ }^{45}$ Martinez, supra, p. 157.

${ }^{46}$ Narrative of an interesting voyage in the frigate La Princesa, from Manila to San Blas in 1780, and 1781. Translation in La Perouse, op. cit., I. 409. 
bored through the water casks, letting the precious water run out. ${ }^{47}$ Often the seawater found its way into the provisions, and further damaged the food.

Under such conditions it was inevitable that disease, principally scurvy, should break out. Until almost the end of the eighteenth century no long expedition was free from the ravages of this disease. Scurvy and cold were the most powerful obstacles to Spanish navigation of the Pacific. The death list was large, chiefly among the crew, for the commanders were accustomed to take somewhat better provisions for themselves. Many of the diaries of the explorers tell of being forced to turn back because not enough well persons were left aboard to navigate the ship. Vizcaino, with his men dying of hunger, dared not stop to receive food from Indians who offered it, as he did not have men strong enough to raise the anchors. ${ }^{48}$

It was not generally known until Cook's voyage how to prevent scurvy on a long voyage.49 Venegas tells how the crew of a Manila galleon were cured by eating "pitahayas, acid fruits, and fresh meat". ${ }^{50}$ Vizcaino records in his diary the efficacy of a "small fruit like agaves, called juicolystlis". ${ }^{.1}$ Martinez knew somewhat better how to combat the dread disease. His list of remedies included "wild celery, greens, the soft tender shoots of the nettle, and various other plants whose taste is similar to that of the radish leaf in salad". ${ }^{52}$ But none of them knew how to provide for the time when the fresh provisions were exhausted, so scurvy long remained the chief hazard and cause of mortality of Spanish seamen.

47 Ibid., I. 366, 367.

48 Diary, 1602-1603. Translation in Bolton, op. cit., p. 98.

49 "Lemon juice as a specific against scurvy was known more than two hundred and fifty years ago, as is shown in The Surgeon's Mate or Military and Domestic Medicine; by John Woodfall, Master in Surgery; London, 1636; and was first introduced into nautical diet in 1795, through the efforts of Drs. Blair and Gilbert Blane, Commissioners of the Board for sick and Wounded Seamen." Frank W. Reilly, "American commerce and the service," in Annual Report of the Supervising Surgeon of the Marine-Hospital Service of the United States, 1874, p. 128, note b.

50 Vol. II. 124.

61 Diary, 1602-1603. Translation in Bolton, op. cit., p. 99.

52 P. 175. 


\section{THE SEAMEN OF THE INDIA TRADE ROUTE}

Trade between Spain and America (called India in those days) during the colonial period was for the most part conducted by great merchant fleets, or flotas, convoyed by one or more vessels of the royal armada. This precaution was necessitated by the raiding of Spanish commerce by foreign buccaneers, for these ships carried the coveted treasures of New Spain, and of the Orient, brought to New Spain in the Manila galleons. For a short time in the middle of the sixteenth century, when danger seemed least, all restrictions upon sailings were removed, but in 1555 the flotas were restored. There were two main fleets, the one with ships for the Gulf of Mexico, the other bound for the ports on the north coast of South America. Vera Cruz and Porto Bello were the destination ports which served the Mexican and Peruvian trade.

Commerce with America was a monopoly in the hands of the merchants of Seville, Spain, organized into the Universidad de los Mareantes. This organization resembled the English gild merchants, in that boatswains, mates, and mariners, as well as owners, masters, and pilots, were included in the membership. The mariners, however, were not allowed to hold office, nor to vote, but received certain privileges, of which more will be said later.

There was much variation in the composition of the flotas and the size of the ships. Five hundred and fifty tons were decreed as the maximum allowed on the India route, but the difficulty of crossing the bar at San Lucar, in Spain, kept the usual size down to more nearly 100 or 200 tons.

The manning scale of vessels in the India trade fixed by the Ordinance of July 14, 1522, required that every vessel of 100 tons burden must carry at least fifteen mariners (or able seamen), 8 grummets (ordinary or apprentice seamen), and three ship's boys. $^{53}$ In 1552 the scale was raised somewhat, and declared to be as follows: 54 .

${ }^{63}$ Clarence Henry Haring, Trade and Navigation between Spain and the Indies in the time of the Hapsburgs (Cambridge, 1918), p. 272. Hereafter cited as Haring.

54 Manuscript collection of Martin Fernandez de Navarrete, 4 vols. (Hydrographic Office, Madrid, 1601-15). XXI. No. 30, cited, Haring, p. 274. 


$\begin{array}{cccc}\text { Size of Ship } & \text { Mariners } & \text { Apprentices } & \text { Boys } \\ 100-170 \text { Tons } & 18 & 8 & 2 \\ 170-220 \text { “ } & 28 & 12 & 4 \\ 220-320 \text { “ } & 35 & 15 & 5\end{array}$

The merchant ships went armed, even to the mariners and passengers. ${ }^{55}$ And it was required that all mariners in the India route should be trained in artillery practice and regulations, and be examined upon the results of their training. ${ }^{56}$

Foreign mariners (except from the Levant) ${ }^{57}$ were prohibited from sailing in the India fleets. ${ }^{58}$ And on the other hand, because of the scarcity of Spanish seamen, Spaniards were forbidden to sail in foreign vessels, unless those ships should be in the service of the India trade, in which case they must be manned by Spaniards. The penalty for breach of this law was four years' service in the galleys. ${ }^{59}$ Only in case of absolute necessity were mariners to be enlisted in the Indies, and then, upon selection of the best by examination, only enough, and no more, were to be chosen. ${ }^{\circ 0}$

When it came time to enlist sailors, the general (or admiral) set up his standard. To this standard men came to be examined, and enrolled if found fit. No one was to be shipped as an able seaman who had not served three years apprenticeship as a

${ }^{55}$ Recopilación de leyes de los reynos delas Indias, 3 vols. (Madrid, 1791). Titulo XXX, Libro IX, Ley XXXII. Hereafter cited as, Recopilación.

${ }^{56}$ Ibid., Titulo XXII, Libro IX, Leyes XIII, XIV, and XX.

${ }^{57}$ Ibid., Titulo XXV, Libro IX, Ley XIII.

${ }^{58}$ Ibid., Titulo XXV, Libro IX, Ley XII. Haring, p. 261, citing Encinas, Provisiones, cedulas, capitulos de ordenancas, 4 vols. (Madrid, 1596), I. 459, 461, says that the prohibition "soon broke down. A royal decree of January, 1590, admitted any stranger of Roman faith, save only the English; another of April, 1595, admitted as masters or pilots in the New Spain fleet all but the English, French, and Dutch; and similar decrees are frequent in the first half of the following century." Of Haring's statement the writer finds no support in the Recopilacion. On the contrary, and apparently in contradiction, Ley XII, cited immediately above, which debars foreigners, was promulgated in 1553, and reiterated in 1609 and 1631. Of course it is well known that Spanish laws and decrees for the New World were often more honored in the breach than in the observance.

${ }^{59}$ Recopilación, Titulo XXV, Libro IX, Ley XV.

${ }^{\circ}$ Ibid., Titulo XXV, Libro IX, Ley XIX. 
grummet. ${ }^{61}$ Sailors had to be between twenty and fifty years of age. ${ }^{62}$ Care had to be taken not to enlist passengers as mariners or grummets for this was a favorite method of evading the emigration laws; ${ }^{63}$ nor were mariners to be enrolled as soldiers, for the former were none too plentiful. ${ }^{64}$ On the ship's register was entered the man's name, age, identification marks, place of birth, and his father's name; also the man's rating, or capacity in which he was to serve, together with his rate of pay, and the day. ${ }^{65}$

Sailors were bound to give security that they would serve and earn their pay, and take an oath of obligation. ${ }^{66}$ But his Catholic majesty Philip II, in 1582, decreed that no pay or rations were to be given a sailor unless he could produce a certificate from one of the religious that he had been at confession. ${ }^{67}$

When a mariner was under contract to serve one master, it was illegal for him to contract to serve another. If he did so, the penalty was double the amount of salary he would have earned, and twenty days in prison. The master who enticed him away knowingly, was also punished.68

In the middle of the sixteenth century a gild of merchants engaged in the India trade was organized in Seville. A little later a hospital was founded for mariners who fell sick from the India voyage, or working aboard ship. In 1569 the gild and hospital united as the Universidad de los Mareantes, with the all inclusive membership before enumerated.69 Certain privileges were granted to the Universidad by the king. Those which included the mariners are given by Stevens as follows:

${ }^{61}$ Encinas, op. cit., IV. 152, cited, Haring, p. 277.

62 Jose de Veitia Linaje, Norte de la contratacion de las Indias Occidentales, 2 vols. in 1 (Sevilla, 1672). This work was made use of in the translation and synopsis, Stevens, The Spanish rule of trade to the West-Indies (London, 1702), $\mathrm{p}$.

160. Hereafter cited as Stevens.

${ }^{63}$ Ibid., p. 45.

${ }^{64}$ Recopilación, Titulo XVI, Libro IX, Ley XII.

${ }^{65}$ Stevens, pp. 166, 187, 188.

66 Ibid., p. 166.

67 Ibid., p. 184.

"Recopilación, Titulo XXV, Libro IX, Ley XVIII.

"H Haring, pp. 319, 320. 
. . . That two hundred Ducats per Month be distributed among the Sailors of every Galeon [and ship of the armada and flota], above their Pay, so that no one receive above four Crowns, and that all those who serve in the India voyage shall be rewarded according to the service they do. 8. That those who do not furnish good Provisions, for the Armada's and Flota's, shall be punish'd. 9. That the Admirals do not suffer the Sailors to be abus'd. 10. That Sailors serving aboard the Armada's and Flota's, be exempt from Town Offices, if they think fit. 11. That no Quarters [for troops] be taken up in the Houses of such as serve in the India Voyage. . . . That a Seaman, who has serv'd 20 Years, enjoy for ever after these Privileges, tho' he follow not the Sea. ${ }^{70}$

Besides, mariners were free from arrest for debt. ${ }^{71}$ The royal arm also stretched out to protect the sailors from the extortions practiced upon them by the people of Vera Cruz. To check this evil it was ordered that prices should be no higher to men of the fleet than to the inhabitants. ${ }^{72}$

Judge Peters in 1807 declared that the Spaniards were "the most unkind, and indeed unjust, to their sick mariners of any people; for they neither pay them any wages nor maintain them. . . ."73 The mariners of the India trade thus apparently had an advantage over other sailors of Spain, in that they were entitled to the privileges of the hospital provided by the Universidad at Seville.

The ordinary daily ration for each person in 1534 was one and one-half pounds of bread, two pints of drinking water and another for bathing, and two pints of wine. ${ }^{74}$ Salt pork, fish, beans and peas, oil, vinegar, rice and sometimes cheese and beef were also part of the ration. ${ }^{75}$ In 1665 the allowance in the Windward Flota was as follows:

70 Stevens, pp. 225, 226.

71 Ibid., p. 184.

72 Ibid.

${ }^{73}$ Laberinto de Comercio, lib. tertio, cap. Navigantis, numero 18, cited, Richard Peters, Admiralty decisions, 2 vols. (Philadelphia, 1807), I. Appendix, cvii.

74 Haring, p. 273.

${ }^{75}$ Ibid., p. 278. 


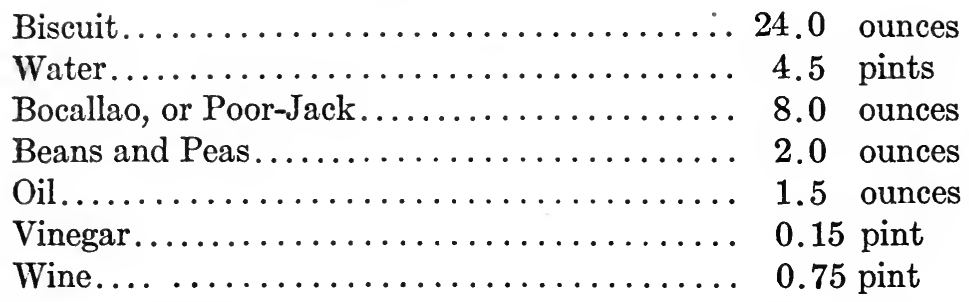

This was the ration for four days in the week. The other three, instead of fish, beans and peas, eight ounces of bacon, an ounce and a half of rice, and a small portion of cheese was substituted. ${ }^{76}$

When rations were cut, sailors were entitled to an indemnification called "pinch gut money". In order to avoid the payment of this, if possible, the Casa de Contratacion, or India House of Trade, issued this precautionary order:

- . that provisions be not shortened without evident necessity, because it has happened that a great quantity of Provisions has by these means, been brought into Port, where the Bisket is sold for the fifth part of its value, which is a very great loss. ${ }^{77}$

Until late in the sixteenth century at least, sailors were hired on shares. The owner of the ship and the sailors each chose a representative to make the settlement at the end of the voyage. The amount of the freight was computed. Then they deducted the amount paid for the convoy service, and two and one-half per cent for distribution as a bounty among sailors and grummets who had rendered extraordinary service. Of the remainder, two thirds went to the owner. The remaining third was apportioned among the crew on the basis of a whole share to each able bodied seaman, two thirds of a share to each grummet, and a fourth to each boy. ${ }^{78}$

Later, sailors shipped for agreed wages, but seem still to have been allowed to carry a limited amount of goods as a private investment. To each mariner was alloted thirty-four jars of wine as his share, and to each grummet ten jars. ${ }^{79}$

76 Stevens, pp. 206, 207.

77 Ibid., p. 174.

${ }^{78}$ Ibid., pp. 222, 223.

79 Recopilación, Titulo XXI, Libro IX, Ley XIII. 
Sailors, grummets, and boys were entitled to four months' advance wages when enlisted. To prevent desertion, no pay was to be given in the Indies, ${ }^{80}$ unless a certificate could be presented proving that the seaman had remained on account of illness, or other legitimate excuse, which prevented him from returning on the same vessel in which he came..$^{81}$ Among the crew of each vessel in the India trade, 200 ducats above the regular pay was to be distributed as a reward for meritorious service. ${ }^{82}$ If the men were not paid promptly within three days of when pay was due, the master was liable to arrest, and for each day's delay, every sailor was entitled to two reals, every grummet to a real and a half, and every boy, one real. ${ }^{83}$

The conditions of life aboard the India ships were much the same as elsewhere among Spanish seamen in the New World. The ships were filthy, crowded, often unseaworthy, and inadequately manned. The prevalence of shipwreck was frightful, and buccaneers abounded. The profits were between 200 and 300 per cent, but the casualties also were enormous.

The principal disciplinary offenses were blasphemy, gambling, immorality, desertion, and crime. It was forbidden for any sailor to go ashore at the Azores under penalty of 200 lashes and ten years in the galleys. ${ }^{84}$ Sometimes mariners deserted before the ships left Spain. ${ }^{85}$ But desertion in the Indies was the most strictly prohibited, as it was the more common also, since many came as seamen to evade the emigration laws.

Permission to go ashore in the Indies was hedged about with restrictions, and every effort was made to ascertain and punish such as planned to desert. Guards were posted on the Porto Bello-Panama road to catch fugitives. India officials and commanders of ships were ordered to do all in their power to apprehend and proceed against deserters, and those who gave them refuge. Some seamen who wished to remain in the Indies sought

\footnotetext{
80 Stevens, pp. 183, 184.

${ }^{81}$ Recopilación, Titulo XXI, Libro IX, Ley XLVI.

s2 Ibid., Titulo XXV, Libro IX, Ley XXII.

${ }^{83}$ Stevens, p. 48.

${ }^{84}$ Ibid., p. 176.

${ }^{85}$ Recopilaeión, Titulo XXXIII, Libro IX, Ley XX
} 
immunity from capture by flight to the altar and other sacred places. Thereupon the king promulgated a law against such immunity, and ordered that such deserters should be taken from the altar and returned to Spain. ${ }^{86}$

These were the conditions under which Spanish sailors lived and labored. If Spanish officials complained of the scarcity of mariners, the cause of the scarcity is readily to be found in the conditions which prevailed in the calling.

\section{THE MERCHANT SEAMEN OF THE PACIFIC}

The discovery of a return route from the Philippines to Mexico by Urdaneta in 1565 made possible for the first time the establishment of a direct trade route across the Pacific Ocean. A regular trade was soon opened between Manila and Spain, by way of Mexico. The Pacific commerce was restricted to one or two annual galleons sailing between Manila and Acapulco, in Mexico. These Manila galleons, as they were called, were fitted out at royal expense and commanded by a royal officer. In size they ranged from small pinks ${ }^{87}$ to galleons of 2000 tons, ${ }^{88}$ but the more usual size, when there were two annual ships, was not larger than 500 tons, carrying crews averaging about 115 men. ${ }^{89}$ The last galleon sailed from Manila in 1811, and returned in 1815. The commerce then fell into private hands, and the ports of San Blas, Guayaquil, and Callao were opened to engage in it. ${ }^{90}$

s6 Ibid., Titulo IV, Libro I, Ley III.

a7 Domingo Fernandez Navarrete, An account of the empire of China. Translation in [Churchill, Awnsham] comp., A collection of voyages and travels (London, 1752), I. 1-311. See p. 213.

ss Admiral Sir Samuel Cornish, to Cleveland, Manila Bay, November 10, 1762. In Blair and Robertson, XLIX, 57-59. See p. 58.

39 Antonio Jose Alvarez de Abreu, Extracto historial del expediente que pende en el consejo real, y supremo de las Indias, a instancia de la ciudad de Manila, y demds de las Islas Philipinas, sobre la forma en que se ha de hacer, y continuar el comercio, y contratacion de los texidos de China en Nueva-España (Madrid 1736). Translations of parts of this work are in Blair and Robertson, XLIV.227-312, and XLV. 29-88. See XLIV. 279.

90 Edward Gaylord Bourne, Historical introduction in Blair and Robertson, I. 66 . 
There was some trade on the Pacific from the earliest days of the conquest, between Mexico and Peru, but it was restricted to an annual galleon, and during some periods, prohibited altogether. The annual supply ships from San Blas to Alta California were not for commercial purposes. Both routes were insignificant in comparison to the Manila-Acapulco line.

The voyage to Manila ordinarily required from seventy-five to ninety days, but the return to Acapulco usually took from seven to nine months, owing to the necessity of sailing northward beyond the belt of trade winds into the westerlies. ${ }^{91}$ America was approached in the latitude of Cape Mendocino; then the galleons turned southward, and sailed along the California coast down to Acapulco. By a renowned traveler who made the voyage to Mexico in 1697 , it was characterized as

the longest, and most dreadful of any in the world; as well because of the vast ocean to be cross'd, being almost the one half of the terraqueous globe, with the wind always a-head; as for the terrible tempests that happen there, one upon the back of another, and for the desperate diseases that seize people, in seven or eight months lying at sea, some times near the line, sometimes cold, sometimes temperate, and sometimes hot, which is enough to destroy a man of steel, much more flesh and blood, which at sea had but indifferent food. ${ }^{92}$

The crews which manned the galleons were composed chiefly of Spaniards and Filipinos (Indians, as they were called). The Spaniards were the sailors, or mariners, corresponding to what we know as able seamen. The Indians were rated as common seamen, corresponding to a lower rating such as our ordinary seamen. Spaniards, too, sometimes sailed as common seamen, but their wage was very much higher than Indian seamen of the same rating. ${ }^{93}$ The difference in wage, however, was not based upon difference of ability, for the seamanship of the natives was

91 Ibid., Blair and Robertson, I. 65.

${ }^{92}$ Giovanni Francesco Gemelli Careri, A voyage round the world. Translation in Churchill, supra, IV. 1-658. See p. 453.

${ }^{93}$ Sebastian Hurtado de Corcuera. Reformacion de suelos y raciones, September 4, 1635. Translation in Blair and Robertson, XXVI. 198-215. See p. 206. 
universally accorded high praise. Viana's description is as follows:

. . There is not an Indian in those islands who has not a remarkable inclination for the sea; nor is there at present in all the world a people more agile in manoeuvers on ship board, or who learn so quickly nautical terms and whatever a good mariner ought to know. Their disposition is most humble in the presence of a Spaniard, and they show him great respect; but they can teach many of the Spanish mariners who sail in these seas. . . There is hardly an Indian who has sailed the seas who does not understand the mariner's compass, and therefore on this [Acapulco] trade-route there are some very skilful and dextrous helmsmen. Their disposition is cowardly, but, when placed on a ship, from which they cannot escape, they fight with spirit and courage..$^{94}$

Common seamen could be secured without difficulty, the natives being ready to volunteer in spite of the great risks and hardships of the voyage. ${ }^{95}$ But with many of them, shipping as seamen was merely the chance to escape from captivity or worse conditions in the Islands. Once in Mexico they deserted and remained there. ${ }^{96}$ With the Spanish sailors, conditions were somewhat different. Appeals were continually sent from Manila to the king, asking for more sailors, who were sent out from Spain to Mexico, where they boarded the galleon for the Philippines. ${ }^{97}$ And it was deemed necessary to provide additional payment for sailors, by increasing the allowance of goods carried

94 Francisco Leandro de Viana, Demonstracion del misero deplorable estado de las Islas Philipinas, Manila, February 10, 1765. Translation in Blair and Robertson, XLVIII. 197-338. See p. 301.

${ }_{95}$ Pedro de San Pablo, O. S. F., Advirtio qve invia a su magd. Fr. Po. de sant Pablo Predicador y ministro Prouincial de la Proua. de st Grego. Dilao, August 7, 1620. Translation in Blair and Robertson, XIX. 71-76. See p. 74.

${ }^{96}$ Captain Sebastián de Pineda, Relacion hecha por el . . en cosas tocantes a las yslas filipinas ainsi de fabricas de galeones pataches y galeras y otros pertechos como de cosas tocantes a la guarda y conserbacion de dichas yslas. [Mexico, 1619?] - Translation in Blair and Robertson, XVIII.169-188. See p.183.

${ }^{77}$ Dr. Santiago de Vera, Copia de carta del governador de Filipinas al Arzobispo de Megico, Manila, June 20, 1585. Translation in Blair and Robertson, VI.66-75. See p.72. And, Diego Aduarte, O.P., Historia dela provincia del Sancto Rosario de la Orden de Predicadores en Philipinas, Iapon, y China (Manila, 1640). Translations of the essential parts of this work, with synopses of those parts omitted, in Blair and Robertson, XXX., XXXI., and XXXII. See XXX. 203. 
as private investment, in order to encourage Spanish seamen to enter the Acapulco trade. ${ }^{98}$ In 1724 hardly one third of the men aboard the galleon were of Spanish birth. ${ }^{99}$ Yet notwithstanding the scarcity of Spanish mariners, foreign sailors were barred from the South Sea by royal decree in 1572. ${ }^{100}$

The sailors of the galleons were a rough class of men, discontented, ${ }^{101}$ living hard, hazardous lives, and dying in poverty and discomfort. ${ }^{102}$ They were variously described by men of the time as "the poor sailors in the continual dangers of their fearful duty" ;103 as "a class of men who lack pity, and have too much greed"; ;04 and as "an ungodly people, guilty of sins of the flesh as well as other offenses, who know naught except to commit offenses against those with whom they deal". ${ }^{105}$ Doubtless the descriptions fitted the subject. Los Rios submitted as one of his recommendations to the king

- . That slave women be not conveyed in the ships, by which many acts offensive to God will be avoided. Although that is prohibited by your royal decree, and it is also entrusted to the archbishop to place upon them the penalty of excommunication and to punish them, this evil has not been checked; and many sailors-and

98 Dr. Santiago de Vera, Carta del Presidente de la Audiencia de Filipinas, Manila, July 13, 1589. Translation in Blair and Robertson, VII. 83-94. See pp. 87, 88. See also Alvarez de Abreu, op. cit., Blair and Robertson, XLIV. 307.

${ }^{99}$ Alvarez de Abreu, loc. cit.

100 Stevens, p. 253.

101 Licientiate Andrés de Alcarez [Letter to Felipe III.], Manila, August 10, 1617. Translation in Blair and Robertson, XVIII. 31-56. See p. 36.

102 Licientiate Gaspar de Ayala, Carta del . . fiscal de la Audiencia de Filipinas, Manila. July 15, 1589. Translation in Blair and Robertson, VII. 112-136. See p. 125 .

${ }^{103}$ Andres de San Nicolás, Recollect, Historia general de los religiosos descalzos del Orden de los Ermitaños del gran Padre y Doctor de la Iglesia San Avgvitin, de la congregacion de España, $y$ de las Indias (Madrid, 1664). Translation of the parts relating to the Philippines in Blair and Robertson, XXI. 111-185. See p. 183.

104 Casimiro Diaz, O.S.A., Conquistas de las Islas Filipinas . . . (Valladolid, 1890). Translations and synopses of excerpts in Blair and Robertson, XXV. 151-200; XXIX. 259-276; XXXVII. 149-284; XLI. 294-296; XLII. 117-312; XLV. 170-173. See XXXVII. 212.

${ }^{105}$ Miguel de Benavides, O.P., Carta del obispo de Nueva Segovia que trata del estado de Manila, Tulac, May 17, 1599. Translation in Blair and Robertson, X. 190-197. See p. 194. 
even others, who should furnish a good example-take slave women and keep them as concubines. ${ }^{106}$

The Indian seamen who deserted at Acapulco, although married in the Islands, did not hesitate to remarry in Mexico. ${ }^{107}$ On the Espiritu Santo in 1618, seventy-five Indians came as common seamen, but not more than five returned. ${ }^{108}$

In the Philippines, the king encouraged the marriage of poor Spanish sailors with native women, and interested himself in the provision of dowries for the Indian women for this very purpose. ${ }^{109}$ His Catholic majesty also found it necessary to establish hospitals, and provide physicians and care for both Indian and Spanish sailors and seamen, whose poverty was such that they could not provide for themselves. Said the king in his instructions to the governor of the Philippines,

. . . I have been told that . . . both of them suffer extreme need; . . Both classes die in discomfort, through having no building in which to be protected from the ravages of the climate, and through the lack of beds, food, medicines, nurses, and other necessities. ${ }^{110}$

Such was the type, and status of the men who manned the galleons.

Very early it was decreed that sailors and common seamen should be examined before enlisting to determine their fitness for the duties at sea. ${ }^{111}$ This proved to be necessary for the reason that often as many as half those listed as sailors on the galleon were not sailors at all, but persons who had secured the position through favoritism in order to gain passage, and to share in a

${ }^{105}$ Hernando de los Rios Coronel, [Reforms needed in the Philippines], (Madrid 1619?). Translations of two documents in Blair and Robertson, XVIII. 289-309, and XVIII. 309-342. See XVIII. 300, 301.

${ }^{107}$ Pineda, op. cit., in Blair and Robertson, XVIII. 184.

${ }^{103}$ Ibid.

${ }^{109}$ Felipe II, Ynstruccion a Gomez Perez Dasmarinas, San Lorenzo, August 9, 1589. Translation in Blair and Robertson, VII. 141-172. See p. 157.

110 Ibid., VII. 143, 144.

${ }^{111}$ Felipe II, and Felipe III, [Laws regarding navigation and commerce.], June 14, 1583-July 25, 1609. Translation of excerpts in Blair and Robertson, XXV. 23-37; XVII. 27-50. See Law XL, Blair and Robertson, XVII. 36. 
profitable trade. 112 And natives from the interior, ignorant of the art of sailing, were often enrolled and shipped by the factor. ${ }^{113}$

The pay received by sailors in 1635 was reported to be 150 pesos per year and 30 gantas of cleaned rice per month for sailors; Spanish common seamen received 100 pesos and 30 gantas of rice; Indian common seamen received 48 pesos and 15 gantas of rice. ${ }^{114}$ In 1637 wages were higher, sailors receiving 175 pesos and common seamen 60 and one half pesos. ${ }^{115}$ Gemelli Careri in 1697 gave sailors' wages as 350 pieces of eight for voyage from Manila to Acapulco and return. Seventy-five pieces of eight were paid at Cavite as advance pay, which was customary; but to prevent desertion at Acapulco, and insure return to Manila, the remaining 275 pieces of eight were not paid until the return, for as Gemelli Careri said, "if they had half, very few would return to the Philippine islands for the rest". ${ }^{116}$

But it was found that wages alone were inadequate. A royal decree had declared that seamen should carry no more boxes or clothing than indispensably necessary, for the reason that they unduly cumbered the ships. In the boxes of course was merchandise carried as a private investment. ${ }^{117}$ But officials in the Philippines protested that wages were insufficient incentive, that greater zeal and willingness to render loyal service would be secured if the men had a stake in the treasure ships, and that more Spaniards would be brought into the service of the Acapulco trade.118 Accordingly permission was granted to carry small amounts, the exact amourit to be allowed being a bone of con-

${ }^{112}$ Los Rios, op. cit., in Blair and Robertson, XVIII. 298.

${ }^{113}$ Ibid., pp. 299, 300.

${ }^{114}$ Hurtado de Corcuera, op. cit., in Blair and Robertson, XXVI.206.

115 Juan Grau y Monfalcon, Memorial informatorio al rey nuestro señor en sv real y svpremo conseio de las Indias. . . . Sobre las pretensiones de aquella comercio con la N ueva España (Madrid, 1637). Translation in Blair and Robertson, XXVII. 55-212. See p. 130.

116 Gemelli Careri, op. cit., in Churchill, IV. 463.

${ }^{117}$ Felipe II, and Felipe III, supra, Law LII, in Blair and Robertson, XVII. $48,49$.

${ }^{113}$ Licientiate Cristóbal Tellez de Almazen, Carta de la Audiencia, Manila, July 6, 1606. Translation in Blair and Robertson, XIV. 140-148. See p. 145. Also, Alvarez de Abreu, op. cit., in Blair and Robertson, XLIV. 271, 307. 
tention between Philippine officials, who sought to raise it, and Spanish officials, who sought to lower it. ${ }^{119}$

But even with a fixed rate of wages, and permission to carry goods for investment on his own account, the pay of the sailor was by no means certain. In 1589 one of the Philippine officials wrote to the king of grave evils existing in this matter.

- . They should be paid in Nueva España as this treasury is too poor. As the money for their wages must be sent, sometimes it is not brought, and at other times it is lost, thereby causing the sailors to die of starvation. Therefore the sailors serve half-heartedly, and desert; and there is great negligence in the dispatch of the fleets. ${ }^{120}$

A decree in accord with the recommendation was promptly issued. ${ }^{121}$

Wages were not paid in money, but by a warrant, or voucher, which was supposed to be convertible into cash-and was, but not when presented by the sailor. In 1621 the archbishop of Manila wrote to the king as follows:

One could not believe the injury that is done to the soldiers and sailors, and to all the wage-earners, by not paying the vouchers earned by their labor and sweat; and on the other hand, by buying these for much less than their face value. For, being rendered desperate, they sell vouchers valued at one thousand pesos for one hundred, and the lamentable thing is that, if they did not sell them, they would never be paid. Scarcely have they sold the vouchers when they are immediately paid, and the purchasers even take the poor wretches to the office of accounts, so they may be present at the payment, and that it may appear justified, by their saying that they did it of their own accord, for which they give a receipt. As it is the price of blood, and they see that others take that price, it is a grief and sorrow that cries to heaven for redress. . . ..$^{122}$

119 Ibid.

${ }^{120}$ Dr. Santiägo de Vera, Carta del Presidente de la Audiencia de Filipinas, Manila, July 13, 1589. Translation in Blair and Robertson, VII. 83-94. See pp. 87,88 .

${ }^{121}$ Ibid., marginal note.

122 Miguel García Serrano, O. S. A., Estado del Arcobispado de Manila tocante a las cosas de gobierno eclesiastico y segular, Manila, July 30, 1621. Translation in Blair and Robertson, XX. 76-100. See p. 96. 
Fifteen years later this flagrant evil was unabated, and corruption continued to hold full sway. In 1636 another letter to the king again recited the abuse as practiced by corrupt officials.

As for those poor men, they have not been paid in one, three, ten, or fifteen years. They sell their warrants during such times for the fourth, fifth, or sixth part of their face value; and many have been paid at one hundred pesos for one thousand. The warrants are bought by the servants of the auditors, royal officials, governors, and other ministers, and to them is paid the face value. ${ }^{123}$

Besides the abuses which have been mentioned, the sailors were subjected to petty annoyances by the collectors of port dues at Acapulco, who, when examining the former's small chests and wretched belongings, "practice many extortions on them so that many refuse to return". ${ }^{24}$

It is evident that the compensations of the sailors were uncertain at best. And when compared to the 100 to 150 per cent profits commonly made by the merchants, and the severe hardships, petty annoyances, and great risks undergone, one cannot but conclude that the sailors and seamen were but poorly recompensed for their indispensable services in a trade which yielded such enormous profits.

Discipline aboard ship was enforced with severity, though probably the Spanish ships of those days were not worse than aboard many American ships within the memory of men still living. Gambling, swearing and blasphemy, and immorality were all punishable, as of course mutiny, desertion, quarreling, and insuhordination. Putting men in the bilboes, ducking them from the yard arm, keel-hauling, and the lash, were well known forms of inflicting punishment. When the sailors and seamen sought release from discipline by going ashore at Acapulco, and

${ }^{123}$ Sebastian Hurtado de Corcuera, [Letter on administrative and financial affairs.], Manila, June 30, 1636. Translation in Blair and Robertson, XXVI. 150156. See p. 151 .

${ }^{124}$ Los Rios, op. cit., in Blair and Robertson, XVIII. 301. See also Alonso Fajardo de Tenza, [Letter to Felipe III.], Manila, August 15, 1620. Translation in Blair and Robertson, XIX. 90-172. See p. 97. 
behaved as they pleased, the king extended the jurisdiction of the ship's officers to cover the time while they were in port. ${ }^{125}$

Life aboard ship could not have been attractive, except for the glamor which has always surrounded going to sea. Ships in those days were the antithesis of cleanliness. Rats and vermin swarmed over the vessel. The most vivid account of the conditions comes from the experience and pen of Gemelli Careri.

. . the galeon is never clear of an universal raging itch, as an addition to all other miseries . . . the ship swarms with little vermine, the Spaniards call Gorgojos, bred in the bisket; so swift that they in a short time not only run over cabins, beds, and the very dishes the men eat on, but insensibly fasten upon the body. . . there are several other sorts of vermin of sundry colours, that suck the blood. ${ }^{226}$

Besides these discomforts, he, like others, complains of the "terrible shocks from side to side, caus'd by the furious beating of the waves". The galleons were always overladen with merchandise, and the decks were crowded with the chests of the sailors, hen-coops, and bales of goods. The very narrowness of the quarters was distressing, and on one galleon at least, led to civil war which was stopped only through the efforts of the fathers who were aboard.127

Provision for rations aboard ship was most unsystematic and improperly attended to. In the first place, those who furnished the rations for the crew often put in food of poor quality. ${ }^{128}$ Then also, the passengers and religious, who were often numerous, consumed food provided for the crew. ${ }^{129}$ Stowaways were an additional drain upon provisions. ${ }^{130}$ So also were the slaves of

${ }^{125}$ Sebastián Hurtado de Corcuera, [Letter to Felipe IV.], Cavite, July 11, 1636. Translation in Blair and Robertson, XXVI. 269-290. See pp. 272, 273.

${ }^{126}$ Gemelli Careri, op. cit., in Churchill, IV. 464.

127 Aduarte, op. cit., in Blair and Robertson, XXX. 129.

${ }^{128}$ Admiral Hieronimo de Bañuelos y Carillo, Relacion de las islas Filipinas (Mexico, 1638). Translation in Blair and Robertson, XXIX. 66-85. See p. 84 .

${ }^{129}$ Recopilación de leyes, libro IX, titulo XXVI, ley IX, cited in Blair and Robertson, XVII. 133.

130 Gregorio López, S. J., [Relation of 1609-1610], Manila, July 1, 1610. Translation in Blair and Robertson, XVII. 100-143. See p. 133. 
the passengers and sailors, who in addition stole whatever food they could lay hands upon; ${ }^{131}$ for even the slaves who aided the sailors in their necessities were not provided for by the king's allowance of food and water. ${ }^{132}$ For these reasons the sailors had to spend their wages buying provisions for themselves and their slaves. This was often the cause of overloading the ships, and was responsible for failure to carry the proper kinds of food, because of which the Indian common seamen suffered most, since they were less used to provide for themselves than the Spanish sailors. ${ }^{133}$ The Indians were even permitted to die of hunger and thirst aboard ship for lack of adequate provision and care. ${ }^{134}$ The various messes aboard stocked themselves as best they could. Swine, hens, fruit, and an abundance of greens were put on the deck until the ship looked like a floating garden.

But these never lasted the entire voyage. If fish could be caught en route the passengers and crew were fortunate, for the food became corrupted, and the water gave out unless the supply could be replenished from the rainfall.

Gemelli Careri, who traveled as a cabin passenger, gives the most graphic account of the hardships and fare aboard the galleon. Eating at the boatswain's mess, he began with fresh fowl, but ere long he found himself eating the king's allowance of rations to the men, of which he gives us a description.

At last he depriv'd me of the satisfaction of gnawing a good bisket, because he would spend no more of his own, but laid the king's allowance on the table; in every mouthful whereof there went down abundance of maggots and Gorgojos chew'd and bruis'd. On fish days the common diet was old rank fish boil'd in fair water and salt; at noon we had Mongos, something like kidney beans, in which there were so many maggots, that they swam at the top of the broth, and the quantity was so great, that besides the loathing they caus'd, I doubted whether the dinner was fish or flesh. This bitter fare was sweeten'd after dinner with a little water and sugar; yet the allowance was but a small cocoa shell full, which rather increased than quenched drought.

\footnotetext{
${ }^{131}$ Los Rios, op. cit., in Blair and Robertson, XVIII. 301.

132 Ibid.

123 Ibid., p. 325.

134 Ibid., p. 300.
} 
Providence reliev'd us for a month with sharks and Cachorretas the seamen caught, which, either boil'd or broil'd were some comfort. Yet he is to be pity'd who has another at his table; for the tediousness of the voyage is the cause of all these hardships. 'Tis certain, they that take this upon them, lay out thousands of pieces of eight in making the necessary provision of flesh, fowl, fish, bisket, rice, sweetmeats, chocolate, and other things; and the quantity is so great, that during the whole voyage, they never fail of sweetmeats at table, and chocolate twice a day, of which last the sailors and grummets make as great a consumption, as the richest. ${ }^{135}$

On solemn feast days an extra allowance of rations was served out. An interesting custom, related by Gamelli Careri, of the Sailor's Court of Signs (held aboard the galleon when the first signs of approach of land appeared), depicts a happier side to the life of the sailors.

- . A canopy being set up for the sailors court of Senas, or signs, after dinner the two Oydores or judges and the president took their seats, being clad after a ridiculous manner. They began with the captain of the galeon, chief pilot, . . . and other officers of the ship; and after them proceeded to the trial of the passengers. The clerk read every man's indictment, and then the judges pass'd sentence of death, which was immediately bought off with money, chocolate, sugar, biscuit, flesh, sweetmeats, wine and the like. ${ }^{136}$

These payments seem to have satisfied a turbulent and not too well fed crew, who, were they not appeased, were ready to inflict the kind of punishments with which they were most familiar.

- . The best of it was, that he who did not pay immediately, or give good security, was laid on with a rope's end at the least sign given by the president-tarpaulin. I was told a passenger was once kill'd aboard a galeon, by keelhauling him; for no words or authority can check or persuade a whole ship's crew. . . The sport lasted till night, and then all the fines were divided among the sailors and grummets, according to custom. . $^{137}$

${ }^{135}$ Gemelli Careri, op. cit., in Churchill, IV. 464.

136 Ibid., p. 467.

${ }^{137}$ Ibid. 
This picture of the Court of Signs, and others of amusements for crew and passengers - cockfighting, plays, dancing, and other entertainments - show that there was a lighter side to the life of the sailor aboard ship. But from the viewpoint of today, the balance seems to have been all the other way.

His very calling was hazardous in the extreme. It was not at all uncommon for men to be washed overboard and drowned by the huge waves which at times swept over, and well-nigh submerged the small craft of that day. More than one galleon was wrecked and went down, or was driven back to Manila by storms with half the crew lost. Then, too, the galleons often sailed poorly repaired through the fault of the shore workers. ${ }^{138}$ Pirates of all nations were active in preying upon such rich treasure ships, and the sailors and seamen might at any time be called upon to defend the ship with their lives against capture by these buccaneers or sea-dogs.

A worse enemy of the seamen, particularly the Indians, was the severe cold encountered on the voyage. They come from a hot climate, and when, without protection, they were exposed to the severities of weather in the higher latitudes, they died in large numbers. They used to come aboard the galleon without clothes, and until the king provided clothing to be issued them as a protection, they had nothing to shelter them. They had no quarters other than the deck, often. Navarrete, describing the situation aboard his ship which was "not convenient nor big enough to celebrate that high mystery" [mass], said: "We had hardly room to stand. No body could live under deck, it was so full of provisions and commodities. All men lay exposed to the sun and air."139

So it happened that many were frozen to death, or died of exposure. The lot of the Indian seamen was especially cruel. As Los Rios said, they were "treated like dogs".

- . . They are embarked without clothes to protect them against the cold, so that when each new dawn comes there are three or four

${ }^{138}$ Los Rios, op. cit., in Blair and Robertson, XVIII, 322.

${ }^{139}$ Fernandez Navarrete, op. cit., in Churchill, I. 213. 
dead men. . . besides, they are treated inhumanly and are not given the necessaries of life, but are killed with hunger and thirst. If he were to tell in detail the evil that is done to them, it would fill many pages..$^{140}$

The Indians, however, were not the only victims of the cold, for the sudden changes of climate, and exposure to wind and rain worked great hardship among all on board, and was the cause of much sickness and death. The treatment of the sick was shamefully neglectful. Gemelli Careri relates the callousness of the captain of his galleon, whose personal profits from the single trip were, according to his own estimate, 25,000 or 30,000 pieces of eight:

Abundance of poor sailors fell sick, being expos'd to the continual rains, cold, and other hardships of the season; yet they were not allow'd to taste of the good bisket, rice, fowls, Spanish bread and sweetmeats put into the custody of the master by the king's order, to be distributed among the sick; for the honest master spent all at his own table. ${ }^{141}$

But the worst danger was from disease. For three centuries European navigators in the New World were afflicted with the scourge of scurvy and beri-beri, especially the former. It was Captain James Cook, the Englishman, who first proved the use of lime juice as an anti-scorbutic, and thus removed one of the greatest hindrances to exploration and maritime commerce. The Spanish navigators paid especially heavy toll to these diseases, the cause of which was lack of fresh provisions, or food containing vitamines. Again we turn to Gemelli Careri for a description of these perils:

- . There are two dangerous diseases in this voyage, more especially as they draw near the coast of America; one is the aforesaid Berben [beri-beri], which swells the body, and makes the patient die talking: The other is call'd the Dutch disease, which makes all the mouth sore, putrifies the gums and makes the teeth drop out. The

${ }^{140}$ Los Rios, op. cit., in Blair and Robertson, XVIII. 300.

${ }^{141}$ Gemelli Careri, op. cit., in Churchill, IV. 464. 
best remedy against it, is going ashore. This is no other, but the sea-scurvy. ${ }^{142}$

The proportion of deaths among the crew and passengers was often enormous. For instance, on one vessel with 400 persons aboard, 208 died before Acapulco was reached. ${ }^{143}$ On another, the San Nicolas, 330 died.144 A voyage on which only three persons died was regarded as most "propitious". ${ }^{145}$ Probably extremely few, if indeed any at all, of the voyages from Manila to America were made without suffering to a greater or less degree from the ravages of these diseases. And on most trips, the sufferings were terrible, and the death list very long.

Small wonder then, that from such a voyage, and such conditions, the survivors frequently preferred to desert at Acapulco (or California, when the galleon stopped there), ${ }^{146}$ rather than return to the Philippines. Wages were paid only in the Philippines, and bonds were required of sailors and seamen in the endeavor to check the large number of desertions in Mexico. ${ }^{147}$

Such were the conditions which prevailed among seamen engaged in Spanish commerce across the Pacific, a trade which flourished for over three centuries.

PaUl S. ThYlor. ${ }^{148}$

University of California.

142 Ibid., p. 468.

${ }^{143}$ Pedro Cubero Sebastian, Peregrinacion del Mundo de. . . (Zaragoza, 1688), p. 268. Quoted, Blair and Robertson, I. 65, 66, note 105.

${ }^{144}$ Alonso Fajardo de Tenza, [Letter to the King.], Manila, December 10, 1621. Translation in Blair and Robertson, XX. 127-155. See p. 128.

${ }^{145}$ Diaz, op cit., in Blair and Robertson, XXXVII, 190.

146 Bancroft, op. cit., XVIII. 484.

147 Sebastian Hurtado de Corcuera, [Letter to Felipe IV.], Cavite, July 11, 1636. Translation in Blair and Robertson, XXVI. 269-290. See p. 284.

148 Acknowledgment is gratefully made for the very helpful guidance and criticism of Professors Herbert Ingram Priestley and Herbert Eugene Bolton. 



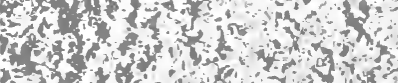

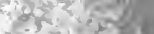
Hisis

ind

,

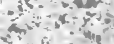

\section{$x^{2}$}

12 




















